DOI https://doi.org/10.18551/rjoas.2018-11.38

\title{
OYSTER MUSHROOM CULTIVATION AS A STRATEGY OF COMMUNITY EMPOWERMENT IN IMPROVING ECONOMIC GROWTH AND DISTRIBUTION OF RURAL AREAS IN INDONESIA
}

\author{
Istikhoroh Siti*, Sukandani Yuni, Arianto Bisma \\ Faculty of Economics, PGRI Adi Buana University of Surabaya, Indonesia \\ ${ }^{*}$ E-mail: istiistitc@gmail.com
}

\begin{abstract}
This article is a literature review on community empowerment and cultivation of oyster mushrooms as one of its strategies. The main concept of empowerment is that people are not only made objects of development, but also subject. There are 3 (three) efforts in community empowerment, namely enabling, empowering, and protecting. These efforts require the involvement of every element of society. The purpose of community empowerment is to establish, enable, and advance people's lives; so that they can participate in development that is people-centered; as well as improving human and institutional resources. One strategy for community empowerment is the cultivation of oyster mushrooms. In addition to not requiring large investments, oyster mushrooms have potential in the market due to the high interest of the Indonesian people towards oyster mushroombased foods.
\end{abstract}

\section{KEY WORDS}

Community, rural, poverty, strategy, business.

Poverty is one of the complex social problems faced by Indonesia untill now. Various analyzes, approaches and strategies are implemented to eliminate poverty, but to date data still shows the ups and downs of the conditions of the poor (Widayanti, 2012). The latest data shows that the poverty rate in Indonesia in March 2018 reached 25.95 million people $(9.82 \%)$ (Indonesian Central Statistics Agency, 2018). There have been many discussions about poverty in Indonesia and all things related to it, ranging from causes to how to overcome them (Hammado, 2016; Kurniawati, Supriyano, \& Hanafi, 2013; Lianah, Umriana, \& Aziz, 2013; Sapar, Palatte, \& Ukkas, 2014; Widjajanti, 2011). Various opinions also state that the natural wealth possessed by Indonesia is actually very sufficient to release its people from the problem of poverty and to improve the welfare of society (Harahap, 2012; Lianah et al., 2013; Sururi, 2015; Widayanti, 2012). But in reality, the condition of the community is very different from what is expected. Until now, poverty is precisely the main problem in the midst of abundant natural resources and potential.

Community empowerment is a concern of various parties and is considered as one of the appropriate approaches in overcoming social problems, especially poverty (Jones, Harris, \& Joseph, 2017; Unni, 2013). Government agencies, businesses and the public have made various efforts related to the empowerment of this community. Even with different perspectives and theoretical foundations, the empowerment program they carry out has the same goal, namely as an effort to resolve or at least reduce the impact of social problems.

Empowerment is the process of developing, building, self-supporting, and strengthening the bargaining position of the lower layers of society against the pressure forces in all fields and sectors of life (Harahap, 2012; Noor, 2011; Perkins \& Zimmerman, 1995; Wilson, 1996; Zimmerman, 1995). Community empowerment can be interpreted as an effort to restore or enhance the empowerment of a community to be able to act in accordance with their dignity in obtaining rights and carrying out their responsibilities as a community and citizen (Harahap, 2012). Community empowerment is also carried out to facilitate local communities in planning, deciding and managing the resources they have so that in the end they have the ability and independence in an economic, ecological and social 
manner in a sustainable manner (Noor, 2011). Therefore, community empowerment is essentially closely related to sustainable development.

Community empowerment as an alternative strategy in the development of a region has developed in various literature, although its implementation has not been maximized (Noor, 2011). Community empowerment is something that is much talked about because it is related to the progress and change of the nation, especially if it is associated with the ability of the community which is still lacking will greatly hamper economic growth itself. Community empowerment as a model of regional development is an effort to improve the dignity of some people who are still trapped in poverty and underdevelopment. The main targets are those who are weak and do not have the power, strength or ability to access productive resources, or marginalized communities in development. The ultimate goal of the community empowerment process is the recovery of human values according to their dignity as a unique, independent and independent person. Unique in the context of human diversity; independence from all internal and external shackles including the bonds of worldliness and poverty; and independent to be able to manage and be responsible for themselves and others. In other words, the purpose of this empowerment is to make the citizens selfsufficient so that they can improve the living standards of their families and optimize their resources.

One of the strategy that can be done in the community empowerment program is the food self-sufficiency program (Lianah et al., 2013) through the cultivation of oyster mushrooms. Oyster mushroom cultivation can be an alternative because it is in accordance with Indonesia's tropical climate, does not require large investments, and the high interest of the Indonesian people in food based on oyster mushrooms. proactive towards policies and social change (Perkins \& Zimmerman, 1995). Empowerment shows participation with other people to achieve goals, efforts to gain access to resources, and some critical understanding of the socio-political environment is a basic component of construction. Empowerment includes organizational processes and structures that increase member participation and enhance the achievement of organizational goals. At the community level, empowerment refers to collective action to improve the quality of life in a community and relations between community organizations. Efforts to gain control, access to resources, and critical understanding of one's socio-political context are fundamental aspects of the empowerment process. (Zimmerman, 1995) Community empowerment is a concept of economic development that summarizes the values of society to build a new paradigm in development that is people-centered, participatory, empowerment and sustainable (Chambers, 1995). The concept of development with a model of community empowerment is not only solely to fulfill the basic needs of the community but rather as an effort to find alternative local economic growth (Noor, 2011). Empowerment is also an act of accepting delegations of power to act in accordance with the mechanisms of individual participation, community networks, organizations and institutions (Ahmad, Yusof, \& Abdullah, 2013). In other words, empowerment is a process of increasing the capacity of individuals or groups to make or change a choice into desired actions and outcomes. The empowering process is a process where people create or are given the opportunity to control their own destiny and influence decisions that affect their lives. They are a series of experiences in which individuals learn to see closer relations between their goals and a sense of how to achieve them, gain greater access and control over resources, and where people, organizations and communities gain control over their lives (Zimmerman, 1995).

The concept of community empowerment. Empowerment is a construction that links individual strengths and competencies, natural assistance systems, and proactive behavior to policies and social change (Perkins \& Zimmerman, 1995). Empowerment shows participation with other people to achieve goals, efforts to gain access to resources, and some critical understanding of the socio-political environment is a basic component of construction. Empowerment includes organizational processes and structures that increase member participation and enhance the achievement of organizational goals. At the community level, empowerment refers to collective action to improve the quality of life in a community and relations between community organizations. Efforts to gain control, access to 
resources, and critical understanding of one's socio-political context are fundamental aspects of the empowerment process (Zimmerman, 1995).

Community empowerment is a concept of economic development that summarizes the values of society to build a new paradigm in development that is people-centered, participatory, empowerment and sustainable (Chambers, 1995). The concept of development with a model of community empowerment is not only solely to fulfill the basic needs of the community but rather as an effort to find alternative local economic growth (Noor, 2011). Empowerment is also an act of accepting delegations of power to act in accordance with the mechanisms of individual participation, community networks, organizations and institutions (Ahmad, Yusof, \& Abdullah, 2013). In other words, empowerment is a process of increasing the capacity of individuals or groups to make or change a choice into desired action and results.

The empowering process is a process where people create or are given the opportunity to control their own destiny and influence decisions that affect their lives. They are a series of experiences in which individuals learn to see closer relations between their goals and a sense of how to achieve them, gain greater access and control over resources, and where people, organizations and communities gain control over their lives (Zimmerman, 1995).

Community empowerment approach. Community empowerment strategy is a process of transformation in the cultural, social, economic and political relations of society. the expected transformation results are an ongoing process. Appropriate intervention is needed in microeconomic theories so that policies at the macro level close the existing gap through empowerment activities in the lower classes (Noor, 2011). Therefore, empowerment can be a bridge for macro and micro development concepts.

Various inputs such as funds, infrastructure and facilities allocated to the community through various development programs must be placed as stimuli to spur the acceleration of community socio-economic activities. This process is directed at increasing the capacity of the community through the accumulation of capital sourced from the surplus generated and in turn can create income enjoyed by the people. Capital fertilization shows that financial assistance, facilities and infrastructure must be managed in an orderly and transparent manner by adhering to the five basic principles. First, it is easy to be accepted and utilized by the community as executor and manager (acceptable); secondly, it can be managed by the public openly and can be accountable; third, provide adequate income and educate the public to manage activities economically (profitable); fourth, the results can be preserved by the community itself so as to create a capital accumulation in the place of a local socioeconomic institution (sustainable); and fifth, fund management and yield preservation can be easily rolled out and developed by the community in a wider scope (replicable) (Kartasasmita, 1997).

"Society is not the object of development, but the subject of development" is the main approach of the concept of empowerment (Kartasasmita, 1997). The concept shows that in carrying out the empowerment process it is very important that the community involvement be empowered so that the objectives of empowerment can be achieved maximally. In the empowerment process, there are two parties that have a very close relationship, first, empowering parties (community workers) and second, empowered (community) parties. Both parties must mutually support each other so that the community as the party to be empowered is not only made an object, but is more directed as a subject. Some approaches that can be used in community empowerment are:

- The empowerment program must be directed. This is so that all efforts in the empowerment program must be aimed at those that really need and are designed to overcome their problems;

- Engaging the community. this aims to help aid and empowerment programs run effectively because people can directly design, implement, manage, and account for the results of their efforts to improve their own economy;

- Using a group approach. This approach is used because in general the community at the bottom is difficult or even unfamiliar with solving their own problems (Noor, 2011; 
Widayanti, 2012; Widjajanti, 2011). In addition, the existence of partnerships between groups can be mutually beneficial and advance the group.

Oyster mushroom cultivation as a community empowerment strategy. Oyster mushrooms are a type of wood fungus that has a higher nutritional content compared to other types of wood fungi. Oyster mushrooms contain protein, fat, phosphorus, iron, thiamin and riboflavin higher than other types of fungi. Every 100 grams of oyster mushrooms contain $19-35 \%$ protein with 9 kinds of amino acids; $1.7-2.2 \%$ fat consists of $72 \%$ unsaturated fatty acids. While mushroom carbohydrates consist of thiamine, riboflavin, and niacin are the main $B$ vitamins in oyster mushrooms, in addition to vitamin $D$ and $C$ minerals they consist of $\mathrm{K}, \mathrm{P}, \mathrm{Na}, \mathrm{Ca}, \mathrm{Mg}, \mathrm{Zn}, \mathrm{Fe}, \mathrm{Mn}$, Co and $\mathrm{Pb}$. Metal microelements are very low so they are safe for consumption every day (Nasution, 2016).

The selection of oyster mushroom cultivation as an alternative in community empowerment is certainly based on several reasons. First, the cultivation of oyster mushrooms is very suitable for tropical regions such as Indonesia. Second, the investment needed to start an oyster mushroom cultivation business is quite cheap and can be done gradually. Third, oyster mushroom cultivation does not require too much land and maintenance is easy and not too expensive. In addition, the waste of oyster mushrooms can be used to make organic fertilizer (Efendi \& Masjudin, 2015). Fourth, various foods made from oyster mushrooms are in great demand by Indonesian people. Fifth, oyster mushrooms can be sold raw or cooked. All of them provide a high level of profit because of the high demand, while the supply from the farmers is only a little. Evidently, the price of mushrooms that have been packaged in unlabeled plastic is twice the price of mushrooms sold by farmers. Prices can be more expensive if the packaging has been labeled. Sixth, doing mushroom business is able to provide a large expected return. Farmers can rent $5 \times 5$ meters of land for one harvest ( 5 months). The land area is enough to put 1000 bag-logs (where mushrooms grow). Each log bag produces 4-5 oyster mushrooms for 4-5 months with a total harvest of about 0.8 to $1 \mathrm{~kg}$. The price of fresh oyster mushrooms in traditional markets is around Rp. 18,000 to 20,000 per $\mathrm{kg}$. Of these reasons, it can be concluded that the development of this business has high prospects for the community because it does not require extensive land and special capabilities in its maintenance, potential market absorption is still very high, and is able to provide high expected return for the community.

Efforts in empowerment of communities. The concept of empowerment tries to break away from the trap of "zero-sum games and trade offs" with the starting point of view that with equality created a broader foundation to ensure sustainable growth. The resulting growth is not only with a smaller cost but also with a small foreign exchange (Browne, 1995), which means that it is very influential for developing countries that experience shortages of foreign exchange and are weak in their balance of payments position. There are 3 (three) efforts in empowering the community (Kurniawati et al., 2013; Noor, 2011), namely:

1. Creating an atmosphere that enables the potential of the community to develop (enabling). This emphasizes that every individual in society has the potential to be developed. Empowerment is an effort to encourage, motivate, and generate public awareness of the potential they have as well as efforts to develop their potential.

2. Strengthening community-owned potential (empowering). This effort can be done through the provision of supporting facilities that can help people develop their potential. Some actions that can be taken are improving education, health, and facilitating access to sources of economic progress such as roads, electricity, schools, and health services that can be accessed by all levels of society, especially the lowest layers. Another action that can be taken is to create a program specifically for people in the lowest layers. This is deemed necessary because general programs that apply do not always touch the community at this level.

3. Protecting the interests of the community (protecting). Empowered communities are often considered weak (Cai, Chew, \& Levy, 2015; Kaur, 2014; Noor, 2011). This protection aims to increase public participation. protecting does not mean isolating or covering from interaction, but rather an attempt to prevent unbalanced competition. 
Community empowerment does not aim to make them dependent on various institutions or government programs. This is because basically the empowerment program tries to teach the community if they want to enjoy something that must be produced from their own efforts (the results of which can be sold or exchanged with other parties). Thus, the goal of establishing, enabling, and advancing a better community life can be achieved. In addition, empowerment is also intended to create community empowerment so that they can participate in people-centered development. Empowerment is not only related to funding but also enhancement of human and institutional resources.

\section{CONCLUSION}

Community empowerment is a concept of economic development that summarizes community values to build a new paradigm in development that is people-centered, participatory, empowerment and sustainable. The concept of development with a model of community empowerment is not only solely to meet the basic needs of the community but rather as an effort to find alternative local economic growth.

Community empowerment strategy is a process of transformation in the cultural, social, economic and political relations of society. The expected transformation results are an ongoing process. Various inputs such as funds, infrastructure and facilities allocated to the community through various development programs must be placed as stimuli to spur the acceleration of community socio-economic activities. The main concept of empowerment is that the community is not only the object of development, but also the subject (implementer). Some approaches that can be used in community empowerment are programs that must be directed, community participation, and group approaches.

In addition, there are 3 (three) efforts in community empowerment, namely enabling, empowering, and protecting. Empowerment also requires the involvement of all elements of society such as government, organizations from outside or within the community, cooperatives, facilitators, and more capable communities. The existence of community empowerment aims to establish, enable, and advance people's lives; so that they can participate in development that is people-centered; as well as improving human and institutional resources.

Oyster mushroom cultivation can be an alternative in improving people's economy. Oyster mushrooms have great potential in improving the economy of rural communities in Indonesia. This business development has several advantages, including not requiring extensive land and special capabilities in its maintenance, the potential for market absorption that is still very high, and able to provide high expected return for the community.

\section{REFERENCES}

1. Ahmad, P., Yusof, F., \& Abdullah, F. (2013). Local Economic Growth and Community Sustainability. Procedia - Social and Behavioral Sciences, 101, 437-444.

2. Badan Pusat Statistik Indonesia. (2018). Profil Kemiskinan di Indonesia Maret 2018. Badan Pusat Statistik (Vol. 29).

3. Browne, C. V. (1995). Empowerment in Social Work Practice with Older Women. Social Work, 40(3).

4. Cai, T., Chew, H. E., \& Levy, M. R. (2015). Mobile value-added services and the economic empowerment of women: The case of Usaha Wanita in Indonesia. Mobile Media and Communication, 3(2), 267-285.

5. Chambers, R. (1995). Poverty and Ilivelihoods: whose reality counts? Environment and Urbanization, 7(1), 173-204.

6. Efendi, I., \& Masjudin. (2015). Pemberdayaan Masyarakat melalui Pembudidayaan Jamur Tiram dan Pengolahan Limbahnya menjadi Pupuk Organik berbasis Koperasi Syari'ah. Jurnal Kependidikan, 14(4), 351-360.

7. Hammado, N. (2016). Pemberdayaan Kelompok Usaha Rumah Jamur dalam Pembuatan Bibit Jamur Tiram di Palopo. In Prosiding Seminar Nasional Hasil-Hasil Penelitian 
Pascasarjana, SPS UNDIP.

8. Harahap, E. F. (2012). Pemberdayaan Masyarakat Dalam Bidang Ekonomi Untuk Mewujudkan Ekonomi Nasional Yang Tangguh Dan Mandiri. Manajemen Dan Kewirausahaan, 3(1), 78-96.

9. Jones, M., Harris, A., \& Joseph, J. (2017). Do micro and small business enterprises economically empower women in developing countries? Evidences from Mekelle City, Tigray, Ethiopia. Journal of Organizational Change Management, 1-17.

10. Kartasasmita, G. (1997). Pemberdayaan Masyarakat: Konsep Pembangunan yang Berakar Pada Masyarakat. In Sarasehan DPD GOLKAR Tk. I Jawa Timur (pp. 1-25).

11. Kaur, I. J. (2014). Economic Empowerment of Rural Women and MGNREGA. Indian Journal of Public Administration, 60(3), 696-719.

12. Kurniawati, D. P., Supriyano, B., \& Hanafi, I. (2013). Pemberdayaan Masyarakat di Bidang Usaha Ekonomi (Studi pada Badan Pemberdayaan Masyarakat Kota Mojokerto). Jurnal Administrasi Publik, I(4), 9-14.

13. Lianah, Umriana, A., \& Aziz, F. (2013). Peningkatan Ekonomi Masyarakat Sriging Patemon Gunungpati Semarang Melalui Budidaya Jamur Tiram. Dimas, 13(2), 405-422.

14. Nasution, J. (2016). Kandungan Karbohidrat dan Protein Jamur Tiram Putih (Pleurotus ostreatus) Pada Media Tanam Serbuk Kayu Kemiri (Aleurites moluccaana) dan Serbuk Kayu Campuran. Jurnal Eksakta, 1, 1-4.

15. Noor, M. (2011). Pemberdayaan Masyarakat. Jurnal IImiah CIVIS, I(2), 87-99.

16. Perkins, D. D., \& Zimmerman, M. A. (1995). Empowerment theory, research, and application. American Journal of Community Psychology, 23(5), 569-79.

17. Sapar, Palatte, M. H., \& Ukkas, I. (2014). Pemberdayaan Kelompok Tani Usaha Budidaya Jamur Tiram Kelurahan Kambo Kecamatan Mungkajang Kota Palopo. Jurnal Equilibrium, 04(02), 124-130.

18. Sururi, A. (2015). Pemberdayaan Masyarakat Melalui Program Pembangunan Infrastruktur Perdesaan Dalam Meningkatkan Kesejahteraan Masyarakat Kecamatan Wanasalam Kabupaten Lebak. Jurnal Administrasi Negara, 3(2), 1-25.

19. Unni, J. (2013). Economic Empowerment of women. Indian Journal of Human Development, 7(2), 364-366.

20. Widayanti, S. (2012). Pemberdayaan Masyarakat: Pendekatan Teoritis. Ilmu Kesejahteraan Sosial, 1(1), 87-102.

21. Widjajanti, K. (2011). Model Pemberdayaan Masyarakat. Jurnal Ekonomi Pembangunan, 12(1), 15-27.

22. Wilson, P. A. (1996). Empowerment: Community Economic Development from the Inside Out. Urban Studies, 33(Nos 4-5), 617-630.

23. Zimmerman, M. A. (1995). Psychological Empowerment: Issues and Illustrations. American Journal of Community Psychology, 23(5), 581-599. 